\title{
Maize Hybrid Response to Sustained Moderate Drought Stress Reveals Clues for Improved Management
}

\author{
Samadangla Ao ${ }^{1}$, Michael P. Russelle ${ }^{2}$, Gary W. Feyereisen ${ }^{3}$, Tamás Varga ${ }^{2}$ \\ and Jeffrey A. Coulter $4, * \mathbb{D}$ \\ 1 Department of Botany, Kohima Science College, Jotsoma, Kohima, Nagaland 797002, India; \\ aoxxx011@umn.edu \\ 2 Department of Soil, Water, and Climate, University of Minnesota, 439 Borlaug Hall, \\ 1991 Upper Buford Circle, St. Paul, MN 55108, USA; russelle@umn.edu (M.P.R.); tvarga@umn.edu (T.V.) \\ 3 United States Department of Agriculture-Agricultural Research Service Soil and Water Management \\ Research Unit, 439 Borlaug Hall, 1991 Upper Buford Circle, St. Paul, MN 55108, USA; \\ gary.feyereisen@ars.usda.gov \\ 4 Department of Agronomy and Plant Genetics, University of Minnesota, 411 Borlaug Hall, \\ 1991 Upper Buford Circle, St. Paul, MN 55108, USA \\ * Correspondence: jeffcoulter@umn.edu
}

Received: 21 August 2020; Accepted: 10 September 2020; Published: 12 September 2020

check for updates

\begin{abstract}
Crop water productivity (CWP), irrigation water productivity (IWP), actual seasonal basal crop coefficient $\left(\mathrm{K}_{\mathrm{ab}}\right)$, and actual crop evapotranspiration $\left(\mathrm{ET}_{\mathrm{a}}\right)$ are essential parameters for accurate estimation of crop water requirement to prevent irrigation water waste. These parameters were evaluated by conducting three experiments using a drought-tolerant maize hybrid and a non-drought-tolerant ('standard') maize hybrid receiving 50,100, and 150\% of the recommended optimal nitrogen $(\mathrm{N})$ fertilizer rate and grown under well-watered conditions, drought stress from the 14 leaf collar maize phenological stage (V14) to maize physiological maturity (R6), and drought stress from the blister maize phenological stage (R2) to R6. Across hybrids, $\mathrm{ET}_{\mathrm{a}}$ decreased with increased duration of drought stress. The drought-tolerant hybrid had 7 and $8 \%$ greater CWP and IWP, respectively, compared to the standard hybrid when drought stress began at V14. Mid-season $\mathrm{K}_{\mathrm{ab}}$ was $1.08,0.89$, and 0.73 under well-watered conditions and when drought stress began at $\mathrm{R} 2$ and V14, respectively. These results reveal that (i) maize achieved more effective physiological acclimation with earlier exposure to drought stress, (ii) grain yield of the drought-tolerant hybrid was unchanged by earlier, compared to later, onset of drought despite a $10 \%$ decrease in $\mathrm{ET}_{\mathrm{a}}$, and (iii) two phases of acclimation were identified: Maize $\mathrm{K}_{\mathrm{ab}}$ declined upon exposure to drought but stabilized as the crop acclimated.
\end{abstract}

Keywords: crop coefficient; drought stress; evapotranspiration; maize; water productivity

\section{Introduction}

Climate change is associated with increased frequency of drought, which is predicted to be more severe and widespread in the future [1]. According to DeLucia et al. [2], the irrigated area of the U.S. Corn Belt will need to expand at least three-fold into areas where rain usually suffices to maintain U.S. maize production at the same level (10.7 $\left.\mathrm{Mg} \mathrm{ha}^{-1}\right)$. Drought adversely affects cereal yields worldwide, with maize (Zea mays L.) having greater sensitivity to drought stress than wheat (Triticum aestivum L.) [3,4]. Crop yield loss due to drought stress can be mitigated by irrigation, but the amount of water available for irrigation is limited. Therefore, judicious management of irrigation 
water requires accurate estimation of the factors used to determine water application [5]. There is great opportunity to improve the efficiency of agricultural water management through enhanced knowledge of crop water use or water productivity (WP) [6-9]. Crop water productivity (CWP) and irrigation water productivity (IWP) are measures of grain production per unit of crop transpiration and volume of irrigation, respectively [9-11].

The effects of drought stress on maize have been studied extensively across a wide range of growing environments [12-14]. Much of the research has investigated WP of maize under different water regimes [15-17]. Reduced CWP under dry conditions is often associated with relatively high water uptake but low grain yield [8]. Greater WP can be achieved when there is maximal soil water absorption for transpiration and minimal water loss through soil evaporation [18].

Compared to conventional irrigation, wherein water is applied as needed to reduce yield loss due to drought stress, deficit irrigation can limit unnecessary evaporation, runoff, and leaching [8]. Compared to irrigation at $100 \%$ of evapotranspiration requirement, irrigation at $75 \%$ of evapotranspiration requirement has been shown to increase CWP of maize with $20 \%$ less actual crop evapotranspiration $\left(\mathrm{ET}_{\mathrm{a}}\right)$ [13]. Djaman and Irmak [14] reported that CWP of maize was maximized at 93 and $100 \%$ of $\mathrm{ET}_{\mathrm{a}}$ of the fully irrigated treatment, while Panda et al. [15] concluded that deficit irrigation should be based on a $45 \%$ maximum allowable depletion of available soil water to achieve high maize grain yield and field water (precipitation plus irrigation) productivity. The phenological stage of crop development affects the amount and timing of water needed for deficit irrigation and thereby influences maize grain yield and WP $[19,20]$. With drought conditions throughout the reproductive phase of maize, irrigation at the milk and dough stages of kernel development has a greater beneficial effect on grain yield of maize than irrigation at later stages [19].

Maize WP increases with increasing nitrogen $(\mathrm{N})$ supply for both deficit and full irrigation up to the $\mathrm{N}$ level required to achieve yield potential at that condition, beyond which an increase in $\mathrm{N}$ supply does not provide additional yield benefit [21]. Adequate $\mathrm{N}$ supply improves WP in maize in part by increasing the crop canopy, which facilitates greater interception of solar radiation and reduces soil evaporation [22]. Compared to no $\mathrm{N}$ fertilization, the application of $120 \mathrm{~kg} \mathrm{~N} \mathrm{ha}^{-1}$ to maize was reported to have no effect on WP in water-limited conditions, but it increased WP by increasing the net photosynthetic rate when ample water was available [16].

Accurate estimation of reference evapotranspiration $\left(\mathrm{ET}_{\mathrm{o}}\right)$, crop evapotranspiration $\left(\mathrm{ET}_{\mathrm{c}}\right)$, and the crop coefficient $\left(\mathrm{K}_{\mathrm{c}}\right)$ is vital for calculating the irrigation requirement. Reference ET is evapotranspiration from a grass reference surface under well-watered conditions, and $\mathrm{ET}_{\mathrm{C}}$ is water loss from a cropped field as a combination of soil surface evaporation and crop transpiration with agronomic management for full production potential [23]. Dual $\mathrm{K}_{\mathrm{c}}$ improves the accuracy of $\mathrm{ET}_{\mathrm{c}}$ estimation because it separates the two independent factors representing the basal crop coefficient $\left(\mathrm{K}_{\mathrm{cb}}\right)$ and evaporation coefficient $\left(\mathrm{K}_{\mathrm{e}}\right)$. The $\mathrm{K}_{\mathrm{cb}}$ is the ratio of $\mathrm{ET}_{\mathrm{c}}$ to $\mathrm{ET}_{\mathrm{o}}$ when the surface soil layer is dry, but when the subsurface layer beyond the zone of evaporation has adequate moisture for transpiration to occur at maximum potential [24]. When crops are grown under environmental stress, a stress coefficient $\left(\mathrm{K}_{\mathrm{s}}\right)$ is used to calculate $\mathrm{ET}_{\mathrm{a}}$ [23]. The soil water balance approach, which is an assessment of the influx and efflux of water into the crop root zone during a period of time, can be used to estimate $\mathrm{ET}_{\mathrm{a}}[6,14,19]$; however, $\mathrm{ET}_{\mathrm{a}}$ and $\mathrm{K}_{\mathrm{cb}}$ vary with crop phenological stage, cultivar, plant-available soil water, and environmental conditions $[6,7]$.

Regional and crop-specific $\mathrm{ET}_{\mathrm{a}}$ and $\mathrm{K}_{\mathrm{c}}$ allow greater precision in crop water management $[7,12,25]$. Previous estimates of $\mathrm{ET}_{\mathrm{a}}$ and WP in maize have been based on full irrigation during the entire growing season, water limitation after the blister stage of maize phenological development (R2), and rainfed conditions, with little emphasis on $\mathrm{K}_{\mathrm{c}}[14,15,26-28]$. There is limited information available on $\mathrm{K}_{\mathrm{c}}$ by the phenological development stage for maize under drought stress [25,29], and to our knowledge none exists for drought-tolerant maize hybrids. Globally, drought stress in maize occurs most frequently during the reproductive stages of development, and in some cases begins as early as the late vegetative 
stages [30-33]. Water requirements of maize are greatest during the late vegetative to early reproductive stages, with drought stress during these stages causing severe yield loss [34,35].

Long-term estimates of maize WP in the western U.S. Corn Belt and China show improvements in CWP over time, which have been attributed to improved cultivars and advances in soil, water, and crop management [36,37]. Improvements in maize grain yield have been associated with enhanced tolerance to drought stress [38,39], and drought-tolerant maize hybrids have potential to alleviate drought-induced yield loss [40-43]. Drought-tolerant hybrids have had greater grain yield and WP than standard hybrids with deficit irrigation at 50 and $75 \%$ of evapotranspiration requirements, although no yield difference was observed in the absence of drought or under severe drought [15,44].

The present study was designed to compare $\mathrm{ET}_{\mathrm{a}}, \mathrm{WP}$, and $\mathrm{K}_{\mathrm{cb}}$ of a drought-tolerant maize hybrid and a standard maize hybrid under well-watered conditions and under moderate drought stress imposed during advanced phenological stages that coincide with natural and increasingly likely drought periods encountered in humid and sub-humid maize-producing regions across the globe.

\section{Materials and Methods}

\subsection{Site Description, Experimental Design, and Cultural Practices}

In 2013, three independent experiments were conducted at the University of Minnesota Sand Plain

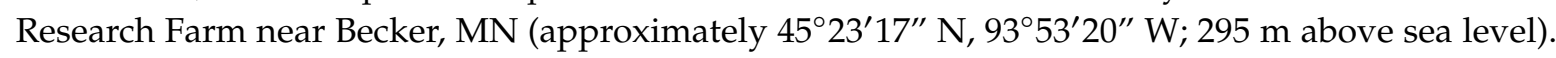
The soil at the study sites was a Hubbord-Mosford loamy sand complex (sandy, mixed, frigid Entic Hapludolls and sandy, mixed, frigid Typic Hapludolls). The soil texture was loamy sand for the 0 - to $45-\mathrm{cm}$ depth layers and sand for the $45-$ to $100-\mathrm{cm}$ depth layers. The mean content of sand, silt, and clay, respectively, was 860,60 , and $80 \mathrm{~g} \mathrm{~kg}^{-1}$ for the 0 - to $45-\mathrm{cm}$ soil depth and 930,10 , and $60 \mathrm{~g} \mathrm{~kg}^{-1}$ for the 45 - to $100-\mathrm{cm}$ soil depth. The soil water content was $0.176 \mathrm{~m}^{3} \mathrm{~m}^{-3}$ at field capacity and $0.084 \mathrm{~m}^{3} \mathrm{~m}^{-3}$ at permanent wilting point within the 0 - to $45-\mathrm{cm}$ depth, and $0.105 \mathrm{~m}^{3} \mathrm{~m}^{-3}$ at field capacity and $0.035 \mathrm{~m}^{3} \mathrm{~m}^{-3}$ at wilting point within the 45 - to $100-\mathrm{cm}$ soil depth [45].

The three experiments were established in close proximity in the same year to make use of spatial and temporal uniformity to increase the accuracy of the results. This enabled precise and timely irrigation application to simulate the drought stress conditions as desired in all three fields without the confounding effects of differences in weather and soil. Each experiment was planted to maize following different previous crops, which were three-year-old alfalfa (Medicago sativa L.), soybean [Glycine max (L.) Merr.], and winter rye (Secale cereale L.) following soybean. Alfalfa and winter rye were terminated with herbicide 10 days before maize planting. All experiments were moldboard plowed seven days before maize planting, then field cultivated and culti-packed on the day of planting. Each experiment evaluated all combinations of three durations of drought stress, two maize hybrids, and three $\mathrm{N}$ fertilizer rates using a split-plot arrangement of these 18 treatments in a randomized complete block design with four replications. Main plot treatments were a duration of drought stress and subplots were a factorial arrangement of hybrid and $\mathrm{N}$ fertilizer rate. Each main plot was $6.0 \mathrm{~m}$ wide by $11.9 \mathrm{~m}$ long, and each subplot was $3.0 \mathrm{~m}$ wide by $4.0 \mathrm{~m}$ long, with maize planted in rows spaced $76 \mathrm{~cm}$ apart. The three durations of drought stress were: (i) a well-watered control, restoring soil water content to field capacity at frequent intervals throughout the growing season; (ii) sustained moderate drought stress from the 14 leaf collar maize phenological stage (V14) to maize physiological maturity (R6); and (iii) sustained moderate drought from R2 to R6. Sustained moderate drought stress in this study resulted in maize leaf rolling beginning around mid-day on nearly every day during the drought-stress period, except on days immediately following irrigation or precipitation. The V14 and R2 stages were selected for the onset of drought stress because maize is most sensitive to drought during the late vegetative to early reproductive stages [34,35], and drought commonly begins around these stages in maize growing regions worldwide [30-33]. Two maize hybrids were used: (i) a designated drought-tolerant hybrid, NK Brand N42Z-3011A, reported to have non-transgenic drought tolerance with a relative maturity rating of 99 and maximum yield potential in all growing 
environments; and (ii) a comparable standard hybrid, NK Brand N36A-3000GT, reported to have a relative maturity rating of 96 and maximum yield in optimum growing conditions.

The three $\mathrm{N}$ fertilizer rates were sub-optimal, optimal, and supra-optimal, representing $\mathrm{N}$ rates that were 50,100, and 150\%, respectively, of the expected economically optimum $\mathrm{N}$ rate for grain yield. Optimum $\mathrm{N}$ fertilizer rates for grain yield were 123,168 , and $213 \mathrm{~kg} \mathrm{~N} \mathrm{ha}^{-1}$ for maize following alfalfa, soybean, and winter rye, respectively, based on research summarized by Rehm et al. [46,47] and Kaiser et al. [48] for highly productive irrigated sandy soils. Nitrogen was applied as $\mathrm{NH}_{4} \mathrm{NO}_{3}$, with $45 \mathrm{~kg} \mathrm{~N}$ $\mathrm{ha}^{-1}$ broadcast immediately after planting and the remaining amount sidedressed as a surface band $10 \mathrm{~cm}$ to the side of each maize row at the six leaf collar maize phenological stage.

Maize was planted on 23 May 2013 in all the experiments. A plant density of 81,500 plants ha $^{-1}$ was achieved by hand thinning at the one leaf collar maize phenological stage. Preemergence and postemergence herbicides were used to control weeds. Additional details on the experimental sites and cultural practices are provided by Ao et al. [49].

\subsection{Soil Water Content Measurement and Irrigation Management}

The soil water content was measured for the 0 - to 20-, 20- to 40-, 40- to 60-, 60- to 80-, and 80to $100-\mathrm{cm}$ soil layers using a time domain reflectometry soil moisture sensor (TRIME-PICO IPH/T3, IMKO GmbH, Ettlingen, Germany) that was inserted into polyvinylchloride access tubes (Schedule 40, $5.25 \mathrm{~cm}$ id). The instrument was calibrated using bulk soil samples collected within the experimental plot area where maize followed soybean [49]. Five days after planting, the access tubes were inserted $1.0 \mathrm{~m}$ deep into the soil after boring holes with a reverse-taper bit on a hydraulically-driven soil tube (Giddings Machine Co., Windsor, CO, USA). Within a plot, the tubes were positioned between the center two maize rows at 9.5 and $28.5 \mathrm{~cm}$ from one of the rows. Due to time constraints for tube placement and frequent measurement of soil water content throughout the season, the access tubes were placed in the selected treatments that were chosen based on their potential to provide meaningful treatment comparisons. In the experiment where the previous crop was soybean, access tubes were placed in all replications of treatments of both hybrids receiving the optimal $\mathrm{N}$ rate and all three durations of drought stress. In the experiments where the previous crop was alfalfa or winter rye, access tubes were placed in all replications of treatments of the drought-tolerant hybrid receiving the optimal $\mathrm{N}$ rate and all three durations of drought stress, and in the treatment combination representing the optimal N rate, standard hybrid, and drought stress from V14 to R6.

At the time of maize emergence, three soil cores per block (i.e., replication) in each experiment were collected from the 0 - to $1.0-\mathrm{m}$ depth using a hydraulically driven soil tube with an inner diameter of $4.1 \mathrm{~cm}$. Each soil core was separated into $20-\mathrm{cm}$ increments and gravimetric soil water content was determined using the oven-drying method [50]. Gravimetric soil water content was then converted to volumetric soil water content and the sum of the values from the 0 - to 1.0-m depth was considered as soil water storage at maize emergence. From the 12 leaf collar maize phenological stage (V12), prior to the application of different irrigation amounts to the drought stress treatments, until R6, soil water content was measured from plots with access tubes once per week unless precipitation occurred, in which case measurements were postponed to the day before the scheduled irrigation (six- to eight-day intervals). Total soil water content in the 0 - to $1.0-\mathrm{m}$ soil profile was used to calculate soil water deficit to determine irrigation water application from the 10 leaf collar maize phenological stage until R6, and for estimating $\mathrm{ET}_{\mathrm{a}}$ throughout the period of measurement $[23,51,52]$ as described in the following sections. A sampling depth of $1.0 \mathrm{~m}$ was used for this study because (i) in these sand-dominated soils, the effective root zone is $\leq 1.0 \mathrm{~m}$; and (ii) sand content in the 80 - to $100-\mathrm{cm}$ soil layer was $93 \%$ with a field capacity of $68 \mathrm{~g} \mathrm{~kg}^{-1}$ and a wilting point of $17 \mathrm{~g} \mathrm{~kg}^{-1}$; thus, plant available water is minimal in this soil layer and also in those below it. Actual crop evapotranspiration, $\mathrm{K}_{\mathrm{cb}}$, and CWP were calculated for the selected treatments containing access tubes for measurement of soil water content, while IWP was determined for all experimental treatments, representing all combinations of three water treatments, three $\mathrm{N}$ rates, and two hybrids in each experiment. 
Uniform irrigation was applied in all drought stress treatments using a solid-set sprinkler system from the 3 to 10 leaf collar maize phenological stages, and using an on-surface drip irrigation system from V12 to the mid-dent maize phenological stage (R5.5) [53]. The drip irrigation system for each experiment had an automated shut-off valve to apply the precise amount of water in each treatment. The drip tapes were connected to polyethylene header pipes $(3.85 \mathrm{~cm}$ id) spaced $11.9 \mathrm{~m}$ apart and located at the front of each main plot (i.e., drought stress treatment). There was one line of drip tape on each side of every maize row. Each line of drip tape was placed $19 \mathrm{~cm}$ from the maize row and had emitters spaced at $15 \mathrm{~cm}$ intervals to achieve uniform distribution of water. One maize row was planted between each pair of adjacent main plots to mitigate edge effects resulting from differential water application. These buffer rows were fertilized with the $50 \% \mathrm{~N}$ rate and did not receive drip irrigation. For treatments with drought stress beginning at V14 and R2, irrigation was limited prior to V14 (21 July) and R2 (12 August), respectively, to achieve the desired moderate drought stress at V14 and R2. Compared to the well-watered control, the treatments with drought stress commencing at V14 and $\mathrm{R} 2$ received reduced amounts of water through drip irrigation beginning at the 12 and 16 leaf collar maize phenological stages, respectively.

A modified checkbook method [54] was used to determine the irrigation amount to apply twice each week. Daily potential crop evapotranspiration was estimated using reference $\mathrm{ET}_{\mathrm{o}}$ [23], weekly volumetric soil moisture data, precipitation, and previous irrigation amounts. At each irrigation event, the amount of water applied in the well-watered treatment brought the soil moisture level back to field capacity, and the amount of water applied in the treatments with drought stress was 60 to $70 \%$ of that applied in the well-watered control [49]. Additionally, for every irrigation decision, a visual observation of maize and the weather forecast of the following few days were taken into consideration. Additional details on drip irrigation management for the treatments are described by Ao et al. [49].

\subsection{Volumetric Soil Water Content Calculation}

Volumetric soil water content was determined for each $20-\mathrm{cm}$ increment within the upper $1.0 \mathrm{~m}$ of soil. The equivalent depth of soil water, $\theta_{\mathrm{p}}(\mathrm{cm})$, for the entire measured depth of the soil profile was calculated as follows [52]:

$$
\theta_{\mathrm{p}}=20\left(\theta_{20}+\theta_{40}+\theta_{60}+\theta_{80}+\theta_{100}\right)
$$

where $\theta_{20}, \theta_{40}, \theta_{60}, \theta_{80}$, and $\theta_{100}\left(\mathrm{~mm}^{3} \mathrm{~mm}^{-3}\right)$ are volumetric soil water content for the 0 - to $20-, 20$ - to 40-, 40- to 60-, 60- to 80-, and 80- to 100-cm depths, respectively. This, along with $\mathrm{ET}_{\mathrm{c}}$, precipitation, and irrigation application, were used to estimate drainage, soil water storage, and $\mathrm{ET}_{\mathrm{a}}$.

\subsection{Crop Coefficient, Soil Water Balance, and Evapotranspiration}

Daily grass reference evapotranspiration was calculated using the Penman-Monteith equation [23, 51]. Daily air temperature and precipitation were obtained from an onsite weather station, maintained and managed by the University of Minnesota. Solar radiation, wind speed, and relative humidity were obtained from the nearest USDA-Natural Resources Conservation Service Soil Climate Analysis Network (SCAN) weather station $[55,56]$ located $6.4 \mathrm{~km}$ away at Crescent Lake, MN (SCAN Site Crescent Lake \#1; $45^{\circ} 25^{\prime} \mathrm{N}, 93^{\circ} 57^{\prime} \mathrm{W} ; 299 \mathrm{~m}$ above sea level) [57]. Vegetation at this SCAN weather station site is grass and the soil is classified as Hubbard sandy loam (sandy, mixed, frigid Entic Hapludolls). The soil texture is sandy loam for the 0 - to $23-\mathrm{cm}$ depth layer, loamy sand for the 23- to $38-\mathrm{cm}$ depth layer, and sand for the 38- to $203-\mathrm{cm}$ depth layers. The SCAN weather stations receive annual preventative maintenance and sensor repair [55]. Incoming hourly data from SCAN weather stations are automatically validated, and values occurring beyond pre-established limits are identified and subsequently evaluated for accuracy based on plots of data over time and comparisons with data for other weather variables from different sensors [56].

Daily $\mathrm{ET}_{\mathrm{c}}$ was estimated as the product of $\left(\mathrm{K}_{\mathrm{s}} \mathrm{K}_{\mathrm{cb}}+\mathrm{K}_{\mathrm{e}}\right)$ and $\mathrm{ET}_{\mathrm{o}}[19,23]$, and was used to calculate deep percolation in the water balance equation. The $\mathrm{K}_{\mathrm{cb}}$ was calculated using the dual $\mathrm{K}_{\mathrm{c}}$ approach, 
accounting for the water-stress coefficient $\left(\mathrm{K}_{\mathrm{s}}\right)$. Dual $\mathrm{K}_{\mathrm{c}}$ is the sum of $\mathrm{K}_{\mathrm{cb}}$ and $\mathrm{K}_{\mathrm{e}}$, reduced by water stress with drought conditions:

$$
\mathrm{K}_{\mathrm{c}}=\mathrm{K}_{\mathrm{cb}} \times \mathrm{K}_{\mathrm{s}}+\mathrm{K}_{\mathrm{e}}
$$

where $K_{c b}$ is the basal crop coefficient, $K_{s}$ is the water stress coefficient, and $K_{e}$ is the soil evaporation coefficient. All terms are unitless.

The basal crop coefficient was calculated for three phases of maize phenological development, representing initial (from the date of emergence to the three leaf collar stage), mid-season (from the 10 leaf collar stage to R5.5), and late-season (from R5.5 to R6) growth phases ( $\mathrm{K}_{\mathrm{cb} \text { ini }}, \mathrm{K}_{\mathrm{cb} \text { mid, and }} \mathrm{K}_{\mathrm{cb} \text { end, }}$ respectively) according to Allen et al. [23]. In all experiments, the maize canopy covered $\geq 80 \%$ of the soil surface at the 10 leaf collar stage of maize phenological development, supporting the use of this crop stage as the beginning of the mid-season growth phase [23]. During rapid canopy development, which in this study was taken from the 3 to 10 leaf collar maize phenological stages, $\mathrm{K}_{\mathrm{cb}}$ is assumed to increase linearly between $K_{c b}$ ini and $K_{c b}$ mid, at which time the full canopy cover reduces $K_{e}$ to minimum values [23]. The values for $\mathrm{K}_{\mathrm{cb} \text { ini }}, \mathrm{K}_{\mathrm{cb} \text { mid, }}$, and $\mathrm{K}_{\mathrm{cb} \text { end }}$ from Allen et al. [23] were used to calculate $\mathrm{ET}_{\mathrm{c}}$. When the daily mean minimum relative humidity was different from $45 \%$ or when wind speed $\left(u_{2}\right)$ at $2 \mathrm{~m}$ was different from $2.0 \mathrm{~m} \mathrm{~s}^{-1}, \mathrm{~K}_{\mathrm{cb} \text { mid }}$ and $\mathrm{K}_{\mathrm{cb} \text { end }}$ values were adjusted as:

$$
\mathrm{K}_{\mathrm{cb}}=\mathrm{K}_{\mathrm{cb}(\text { Table })}+\left[0.04\left(u_{2}-2\right)-0.004\left(\mathrm{RH}_{\min }-45\right)\right](\mathrm{h} / 3)^{0.3}
$$

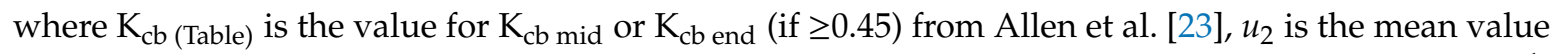
for daily wind speed at a 2-m height over grass during the mid- or late-season growth phase $\left(\mathrm{m} \mathrm{s}^{-1}\right)$ for $1 \mathrm{~m} \mathrm{~s}^{-1} \leq u_{2} \leq 6 \mathrm{~m} \mathrm{~s}^{-1}, \mathrm{RH}_{\min }$ is the mean daily minimum relative humidity during the mid- or late-season growth phase (\%) for $20 \% \leq \mathrm{RH}_{\min } \leq 80 \%$, and $\mathrm{h}$ is the mean height of maize during the midor late-season phase $(\mathrm{m})$ for $20 \% \leq \mathrm{RH}_{\min } \leq 80 \%$. The $\mathrm{K}_{\mathrm{s}}$ was estimated according to Allen et al. [23] as:

$$
\mathrm{K}_{\mathrm{s}}=\left(\mathrm{TAW}-\mathrm{D}_{\mathrm{r}}\right) /[(1-\mathrm{p}) \mathrm{TAW}]
$$

for $D_{r}>(p) T A W$, where $K_{s}$ is a dimensionless transpiration reduction factor based on soil water content $(0-1)$, TAW is total available soil water in the crop root zone $(\mathrm{mm}), \mathrm{D}_{\mathrm{r}}$ is root zone depletion $(\mathrm{mm})$, and $\mathrm{p}$ is fraction of TAW that a crop can extract from the root zone without suffering water stress. The value of $p$ was assumed to be 0.59 , based on the recommendation of Allen et al. [23] for maize on coarse-textured soils.

The soil evaporation coefficient describes the evaporation components of $\mathrm{ET}_{\mathrm{c}}$. When surface soil is wet following rain or irrigation, $K_{e}$ is maximum; when surface soil is dry, $K_{e}$ is small or zero. The $K_{e}$ was determined as [23]:

$$
\mathrm{K}_{\mathrm{e}}=\min \left(\mathrm{K}_{\mathrm{r}}\left(\mathrm{K}_{\mathrm{c} \max }-\mathrm{K}_{\mathrm{cb}}\right), \mathrm{f}_{\mathrm{ew}} \mathrm{K}_{\mathrm{c} \max }\right)
$$

where $K_{r}$ is the dimensionless evaporation reduction coefficient, $K_{c} \max$ is the maximum value of $K_{c}$ following precipitation or irrigation, and $\mathrm{f}_{\mathrm{ew}}$ is the portion of soil that is exposed to solar radiation and wetted. Additional details regarding these equations used for calculating $\mathrm{K}_{\mathrm{cb}}, \mathrm{K}_{\mathrm{e}}$, and $\mathrm{K}_{\mathrm{s}}$ are provided by Allen et al. [23,51].

Actual $\mathrm{ET}_{\mathrm{a}}$ was calculated on six- to eight-day intervals using the water balance equation [23]:

$$
\mathrm{ET}_{\mathrm{a}}=\mathrm{P}+\mathrm{I}-\mathrm{R}-\mathrm{D}+\mathrm{C} \pm \Delta \mathrm{SF} \pm \Delta \mathrm{S}
$$

where $\mathrm{P}$ is precipitation, $\mathrm{I}$ is irrigation, $\mathrm{R}$ is surface runoff, $\mathrm{D}$ is deep percolation below the measured crop root zone, $\mathrm{C}$ is capillary rise, $\triangle \mathrm{SF}$ is change in the horizontal subsurface water flux within the root zone, and $\Delta S$ is change in soil water storage during the measured time interval. All terms are in millimeters per unit time. The $\Delta \mathrm{S}$ was determined using gravimetric soil moisture content measured at maize emergence and volumetric soil moisture content measured at regular intervals from V12 to R6 according to Equation (1). 
Deep percolation was estimated using daily precipitation, soil water content at the time of planting, dates and amounts of irrigation water supplied, effective crop rooting depth, crop phenology, and soil properties. Deep percolation was calculated as follows [15]:

$$
\mathrm{D}_{j}=\max \left(\mathrm{P}_{j}+\mathrm{I}_{j}-\mathrm{R}_{j}-\mathrm{ET}_{\mathrm{cj}}-\Delta \mathrm{CD}_{j-1}, 0\right)
$$

where $\mathbf{D}_{j}$ is deep percolation on day $j, \mathbf{P}_{j}$ is precipitation on day $j, \mathbf{I}_{j}$ is irrigation on day $j, \mathbf{R}_{j}$ is precipitation and/or irrigation runoff from the soil surface on day $j, \mathrm{ET}_{\mathrm{c} j}$ is crop evapotranspiration on day $j$, and $\Delta \mathrm{CD}_{j-1}$ is cumulative depletion depth in the root zone at the end of day $j-1$. All terms are in millimeters per unit time. Surface runoff from the experimental sites was estimated using the curve number method, with a curve number of 75 based on land use and soil properties of the sites [58].

It was assumed that subsurface upward water flux and capillary rise were negligible in the sand and loamy sand soil. Therefore, the soil water balance equation for $\mathrm{ET}_{\mathrm{a}}$ calculation was reduced to:

$$
\mathrm{ET}_{\mathrm{a}}=\mathrm{P}+\mathrm{I}-\mathrm{R}-\mathrm{D} \pm \Delta \mathrm{S}
$$

For comparative purposes, actual seasonal basal crop coefficient $\left(\mathrm{K}_{\mathrm{ab}}\right)$ was determined following a modified approach used by previous researchers for $\mathrm{K}_{\mathrm{cb}}$ calculation under deficit irrigation $[59,60]$. The $\mathrm{K}_{\mathrm{ab}}$ was calculated on six- to eight-day intervals using estimated $\mathrm{ET}_{\mathrm{o}}$ and evaporation (E) according to the equations from Allen et al. [23], and $\mathrm{ET}_{\mathrm{a}}$ was calculated from the field data for the well-watered control and the two treatments with sustained moderate drought stress as:

$$
\mathrm{K}_{\mathrm{ab}}=\mathrm{K}_{\mathrm{cb}} \times \mathrm{K}_{\mathrm{s}}=\left(\mathrm{ET}_{\mathrm{a}}-\mathrm{E}\right) / \mathrm{ET}_{\mathrm{o}}
$$

where $\mathrm{ET}_{\mathrm{a}}$ is actual crop ET $\left(\mathrm{mm} \mathrm{d}^{-1}\right)$ and $\mathrm{ET}_{\mathrm{o}}$ is reference ET $\left(\mathrm{mm} \mathrm{d}^{-1}\right)$. Field-based $\mathrm{K}_{\mathrm{s}}$ was computed using calculated $\mathrm{ET}_{\mathrm{a}}$ and estimated $\mathrm{ET}_{\mathrm{c}}$ based on $\mathrm{K}_{\mathrm{cb}}$ and Allen et al. [23] as:

$$
\mathrm{K}_{\mathrm{s}}=\left(\mathrm{ET}_{\mathrm{a}}-\mathrm{E}\right) /\left(\mathrm{ET}_{\mathrm{c}}-\mathrm{E}\right)
$$

Crop water productivity and IWP of maize were calculated using modified equations from Payero et al. [19]:

$$
\begin{gathered}
\mathrm{CWP}=\mathrm{GY} / \mathrm{ET}_{\mathrm{a}} \\
\mathrm{IWP}=\mathrm{GY} / \mathrm{I}
\end{gathered}
$$

where CWP is crop water productivity $\left(\mathrm{kg} \mathrm{m}^{-3}\right), \mathrm{GY}$ is maize grain yield $\left(\mathrm{g} \mathrm{m}^{-2}\right), \mathrm{ET}_{\mathrm{a}}$ is total seasonal actual crop evapotranspiration (mm), IWP is irrigation water productivity $\left(\mathrm{kg} \mathrm{m}^{-3}\right)$, and I is total seasonal irrigation for a given drought stress treatment $(\mathrm{mm})$.

The date of emergence was 31 May for all treatments and the date of R6 was 24, 20, and 18 September for the well-watered control and the treatments with drought stress beginning at V14 and R2, respectively. Reference evapotranspiration, $\mathrm{ET}_{\mathrm{a}}$, average $\mathrm{K}_{\mathrm{ab} \text { mid }}, \mathrm{CWP}$, and IWP were calculated using a spreadsheet software program from maize emergence to 24 September for all three durations of drought stress. Additionally, we calculated growth-stage-specific $\mathrm{K}_{\mathrm{ab}}$ using $\mathrm{K}_{\mathrm{ab}}$ computed at six- to eight-day intervals from the 10 leaf collar maize phenological stage to R6 from the experiment where maize followed soybean. All possible precautions were taken to achieve precision in the measurement of soil water content and calculation of water balance components $[61,62]$. However, this study used the soil water balance approach to estimate $\mathrm{ET}_{\mathrm{a}}$, which is based on calculations that are reliant upon book values and assumptions. A more direct approach of measuring the influx and efflux of soil water into the crop root zone, such as weight-based lysimetry, may produce more representative estimates of $\mathrm{ET}_{\mathrm{a}}$ [61]. 


\subsection{Maize Grain Yield Measurement}

At R6, maize ears were harvested from the center $2.4 \mathrm{~m}$ of the two center rows of each plot and oven dried at $60^{\circ} \mathrm{C}$ until constant mass, followed by shelling and weighing of grain. Maize grain yield was calculated at $155 \mathrm{~g} \mathrm{~kg}^{-1}$ moisture. A detailed summary of the results of maize grain yield and yield components was reported by Ao et al. [49]. The grain yield data used in this manuscript were (i) analyzed for the treatment combinations with calculated $\mathrm{ET}_{\mathrm{a}}$, (ii) used to determine CWP for these same treatment combinations, and (iii) used with the irrigation amount to calculate IWP for all experimental treatments.

\subsection{Statistical Analysis}

Statistical analysis was performed for three datasets based on the treatments sampled, which represent: (i) all durations of drought stress for both hybrids at the optimal $\mathrm{N}$ rate from the experiment where maize followed soybean; (ii) all durations of drought stress for the drought-tolerant hybrid at the optimal N rate from all experiments; and (iii) drought stress from V14 to R6 for both hybrids at the optimal $\mathrm{N}$ rate from all experiments. Actual crop evapotranspiration, CWP, IWP, maize grain yield, and average $K_{a b}$ mid were analyzed for datasets (i), (ii), and (iii), and growth-stage-specific $K_{a b}$ was analyzed for dataset (i).

Data were analyzed with mixed-effect linear models using the MIXED procedure of SAS [63] at $P \leq 0.05$. Block (nested within experiment), experiment (i.e., previous crop), and interactions with block were considered random effects, duration of drought stress and hybrid were considered fixed effects, and maize phenological stage for $\mathrm{K}_{\mathrm{ab}}$ was considered a fixed effect with repeated measurement. The UNIVARIATE procedure of SAS and scatterplots of residuals versus predicted values were used to assess the normality and homogeneity of variance [64]. Means from significant fixed effects were compared with pairwise $t$-tests using the PDIFF option of the MIXED procedure of SAS.

\section{Results}

\subsection{Growing Conditions and Water Supply}

With the exception of precipitation, weather conditions were within the range for favorable maize growth (Table 1) [65], thereby allowing the imposed drought stress treatments to be evaluated in the absence of other abiotic stresses. Seasonal average air temperature was $19.8^{\circ} \mathrm{C}$ and maximum daily average air temperature for July through August was $29.0^{\circ} \mathrm{C}$. Average seasonal relative humidity was $71 \%$, monthly average wind speed did not exceed $2 \mathrm{~m} \mathrm{~s}^{-1}$ except in June, and the average vapor pressure deficit in July through August was $1.11 \mathrm{kPa}$. Total seasonal $\mathrm{ET}_{\mathrm{o}}$ from maize emergence to R6 was estimated as 469 (Table 2). Compared to $\mathrm{ET}_{\mathrm{o}}$, the estimated total seasonal $\mathrm{ET}_{\mathrm{c}}$ was $25 \mathrm{~mm}$ greater for the well-watered control and 59 and $21 \mathrm{~mm}$ less for the treatments where drought stress began at V14 and R2, respectively, when averaged across experiments. The range of $\mathrm{ET}_{\mathrm{c}}, 409$ to $494 \mathrm{~mm}$, estimated in this study was comparable to $\mathrm{ET}_{\mathrm{c}}$ under deficit irrigation estimated by Trout and DeJonge in a more arid climate with lower relative humidity and $\mathrm{ET}_{\mathrm{o}}[66]$.

Total precipitation from maize emergence to $\mathrm{R} 6$ averaged $258 \mathrm{~mm}$ across all treatments (Table 2). Total precipitation from the 13 leaf collar maize phenological stage to the dough stage of maize was $33 \mathrm{~mm}$, with the highest daily amount of $9 \mathrm{~mm}$ near the tasseling stage (Figure 1). This low amount of precipitation during this period of maize growth, coupled with judicious irrigation amounts, enabled sustained moderate drought stress to be achieved in the treatments with drought stress from V14 to R6 and R2 to R6. Irrigation was applied from the three leaf collar stage of maize phenological development until R5.5 (Tables 2 and 3; Figure 1), although soil water deficits may have occurred beyond this point (Figure 1). Averaged across experiments, total irrigation was 345, 224, and $177 \mathrm{~mm}$ for the well-watered control and treatments with drought stress beginning at R2 and V14, respectively (Table 2). A total of $105 \mathrm{~mm}$ of irrigation was applied from V14 to R6 in the treatment where drought stress began at V14. In the treatment where drought stress began at R2, $67 \mathrm{~mm}$ of irrigation was 
applied from R2 to R6. The approximate deep percolation water loss beyond the effective root zone was $150 \mathrm{~mm}$ in the well-watered control, and 35 and 31\% less in the treatments where drought stress began at V14 and R2, respectively. This study considered the effective root zone to be 0 to $1.0 \mathrm{~m}$, which is supported by the results of total root length density. Averaged across the experiments where maize followed soybean and winter rye, the well-watered control and the treatment with drought stress from V14 to R6, and both hybrids, total root length density of maize after harvest was 13.48, $10.04,1.10,0.44$, and $0.10 \mathrm{~cm} \mathrm{~cm}^{-3}$ for the 0 - to $15-, 15-$ to $30-, 30-$ to $45,45-$ to $60-$, and $60-$ to $90 \mathrm{~cm}$ soil layers, respectively, and the value of $0.10 \mathrm{~cm} \mathrm{~cm}^{-3}$ from the $60-$ to $90-\mathrm{cm}$ soil layer was not significantly different from zero $(P=0.439)$ [67]. However, the measurement of soil water content below the 1.0-m depth in this study may have provided a more comprehensive assessment of soil water balance [14].

At the time of maize emergence, the soil was nearly at field capacity (only $9 \mathrm{~mm}$ soil water deficit) for all three drought stress treatments (Table 2, Figure 1). Across experiments, the average change in water storage from maize emergence to $\mathrm{R} 6 \mathrm{was}-18,-32$, and $-33 \mathrm{~mm}$ for the well-watered control and the treatments where drought stress began at V14 and R6, respectively. During the period of imposed drought stress, the average water storage was 75 and $72 \mathrm{~mm}$, respectively, for the treatments where drought stress began at V14 and R2, and these values were 23 and 19\% of total available water (Figure 1). During the milk stage of maize phenological development on 19 August and 26 August, soil water storage for the well-watered treatment was slightly less than the threshold below which evapotranspiration is reduced to less than potential values (90 mm). This occurred near the time when precipitation was absent for about three weeks, and may have resulted in a slight underestimation of irrigation amount to meet the crop evapotranspiration demand. The treatments with imposed drought stress from V14 to R6 and R2 to R6 experienced soil water storage that was near the permanent wilting point $(57 \mathrm{~mm})$ during the mid-R2 to early dent stages of maize phenological development from 16 August to 8 September. This may have caused maize in these treatments to experience more water stress near this time compared to other times during the period of imposed drought stress. The estimated cumulative growing season evaporation was 91, 98, and $98 \mathrm{~mm}$ for the well-watered control and the treatments where drought stress began at V14 and R2, respectively (Table 2). These values are comparable with the evaporation values reported by others from a semiarid area at the western edge of the central U.S. High Plains [66,68]. Additional details on growing conditions and water supply were reported by Ao et al. [49]. 
Table 1. Monthly average maximum and minimum air temperature $\left(\mathrm{T}_{\max }\right.$ and $\mathrm{T}_{\min }$, respectively), maximum and minimum relative humidity ( $R \mathrm{H}_{\text {max }}$ and $\mathrm{RH} \mathrm{H}_{\text {min }}$ respectively), wind speed, solar radiation, vapor pressure deficit, and reference evapotranspiration $\left(\mathrm{ET}_{\mathrm{o}}\right)$, and monthly total precipitation during the growing season of 2013.

\begin{tabular}{|c|c|c|c|c|c|c|c|c|c|}
\hline \multirow{2}{*}{ Month } & $\mathbf{T}_{\max }$ & $\mathrm{T}_{\min }$ & $\mathbf{R H}_{\text {max }}$ & $\mathbf{R H}_{\min }$ & Wind Speed & Solar Radiation & Vapor Pressure Deficit & $\mathrm{ET}_{\mathbf{o}}$ & Total Precipitation \\
\hline & ${ }^{\circ} \mathrm{C}$ & ${ }^{\circ} \mathrm{C}$ & $\%$ & $\%$ & $\mathrm{~m} \mathrm{~s}^{-1}$ & $M J m^{-2} d^{-1}$ & $\mathrm{kPa}$ & $\mathrm{mm} \mathrm{d}^{-1}$ & $\mathrm{~mm}$ \\
\hline June & 28.8 & 14.3 & 94.3 & 44.1 & 2.3 & 18 & 0.9 & 4.2 & 111 \\
\hline July & 27.6 & 13.3 & 97.5 & 48.0 & 1.9 & 21 & 1.1 & 4.5 & 61 \\
\hline August & 29.9 & 14.4 & 93.8 & 47.2 & 1.3 & 20 & 1.1 & 4.1 & 23 \\
\hline September & 23.0 & 8.1 & 95.0 & 44.3 & 1.7 & 14 & 0.9 & 3.0 & 62 \\
\hline
\end{tabular}

Table 2. Means and standard errors of cumulative water balance components from maize emergence to maize physiological maturity (R6) for plots with the optimal nitrogen rate ${ }^{1}$.

\begin{tabular}{|c|c|c|c|c|c|c|c|c|c|}
\hline Previous Crop & Drought Stress $^{2}$ & $\mathrm{ET}_{\mathrm{o}}{ }^{3}$ & $\mathrm{ET}_{\mathrm{c}}{ }^{4}$ & Precipitation & Irrigation & Surface Runoff & $\Delta S^{5}$ & Deep Percolation ${ }^{6}$ & Evaporation $^{7}$ \\
\hline & & \multicolumn{8}{|c|}{$\mathbf{m m}$} \\
\hline \multirow[t]{2}{*}{ Alfalfa } & None & 469 & 494 & 258 & 345 & 8 & $-26(7)$ & 158 (9) & 91 \\
\hline & R2-R6 & 469 & 448 & 258 & 224 & 6 & $-28(2)$ & $100(3)$ & 98 \\
\hline \multirow[t]{3}{*}{ Soybean } & None & 469 & 494 & 258 & 348 & 8 & $-8(2)$ & $144(2)$ & 91 \\
\hline & R2-R6 & 469 & 448 & 258 & 221 & 5 & $-38(3)$ & $104(2)$ & 98 \\
\hline & V14-R6 & 469 & 411 & 258 & 184 & 4 & $-35(3)$ & $100(2)$ & 98 \\
\hline \multirow[t]{2}{*}{ Winter rye } & None & 469 & 494 & 258 & 346 & 8 & $-19(9)$ & $149(7)$ & 91 \\
\hline & R2-R6 & 469 & 449 & 258 & 224 & 6 & $-33(5)$ & 108 (7) & 98 \\
\hline
\end{tabular}

${ }^{1}$ In the experiment where the previous crop was soybean, the means are from all combinations of three drought stress treatments and both hybrids (standard and drought tolerant). In the
experiments where the previous crop was alfalfa and winter rye, the means are from three drought stress treatments with the drought-tolerant hybrid, and the treatment with drought experiments where the previous crop was alfalfa and winter rye, the means are from three drought stress treatments with the drought-tolerant hybrid, and the treatment with drought stress from the 14 leaf collar maize phenological stage (V14) to maize physiological maturity (R6) with the standard hybrid. Standard errors are within parentheses for those variables with V14-R6: Drought stress V14 to R6. ${ }^{3}$ Reference evapotranspiration calculated using the Penman-Monteith equation [23]. ${ }^{4}$ Estimated crop evapotranspiration according to Allen et al. [23].

${ }^{5}$ Change in soil water storage during the measured time interval. ${ }^{6}$ Estimated deep percolation of water below the measured crop root zone. ${ }^{7}$ Estimated evaporation from wet soil. 


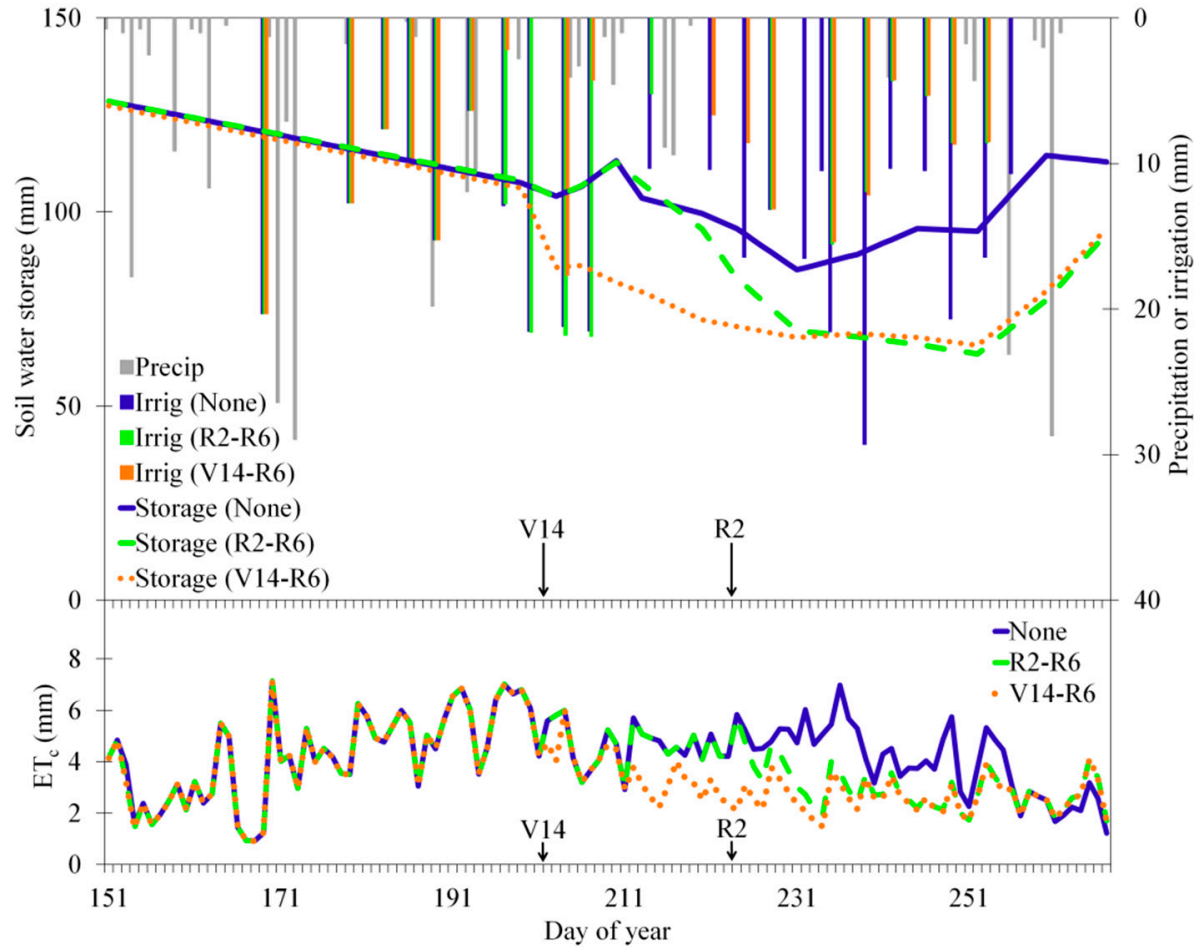

Figure 1. Daily precipitation (Precip), irrigation (Irrig), estimated soil water storage (Storage), and estimated crop evapotranspiration $\left(\mathrm{ET}_{\mathrm{C}}\right)$ from maize emergence (day 151) to maize physiological maturity (R6, day 267) for treatments with no drought stress (None), drought stress from the 14 leaf collar maize phenological stage (V14) to R6 (V14-R6), and drought stress from the blister maize phenological stage (R2) to R6 (R2-R6) that received the optimal nitrogen rate, averaged across experiments. In the experiment where the previous crop was soybean, the values for soil water storage are from all combinations of three drought stress treatments and both hybrids (standard and drought tolerant). In the experiments where the previous crop was alfalfa and winter rye, the values for soil water storage are from three drought stress treatments with the drought-tolerant hybrid, and the treatment with drought stress from V14 to R6 with the standard hybrid.

Table 3. Total monthly irrigation $(\mathrm{mm})$ for treatments with no drought stress (None), drought stress from the blister maize phenological stage (R2) to maize physiological maturity (R6) (R2-R6), and drought stress from the 14 leaf collar maize phenological stage (V14) to R6 (V14-R6) for experiments where maize followed alfalfa, soybean, and winter rye.

\begin{tabular}{cccccccccc}
\hline \multirow{2}{*}{ Month } & \multicolumn{3}{c}{ Alfalfa } & \multicolumn{3}{c}{ Soybean } & \multicolumn{3}{c}{ Winter Rye } \\
\cline { 2 - 10 } & None & R2-R6 & V14-R6 & None & R2-R6 & V14-R6 & None & R2-R6 & V14-R6 \\
\hline June & 33 & 33 & 33 & 33 & 33 & 33 & 33 & 33 & 33 \\
July & 115 & 118 & 61 & 118 & 115 & 68 & 116 & 118 & 62 \\
August & 138 & 50 & 61 & 139 & 50 & 60 & 138 & 50 & 60 \\
September & 58 & 23 & 23 & 59 & 22 & 23 & 58 & 23 & 22 \\
\hline
\end{tabular}

\subsection{Actual Crop Evapotranspiration}

Actual crop evapotranspiration and related CWP, IWP, and $\mathrm{K}_{\mathrm{ab}}$ were evaluated for treatment combinations where volumetric soil moisture measurement access tubes were placed (Tables 4 and 5). In the experiment where maize followed soybean, seasonal $\mathrm{ET}_{\mathrm{a}}$ for the treatment with the optimal $\mathrm{N}$ rate was affected only by drought stress (Table 5). Averaged across hybrids in the experiment following soybean, seasonal $\mathrm{ET}_{\mathrm{a}}$ declined by 56 and $90 \mathrm{~mm}$ when drought stress began at R2 or V14 compared to the well-watered control, respectively (Table 4). Seasonal ET $\mathrm{a}$ for the drought-tolerant hybrid with the optimal $\mathrm{N}$ rate was influenced by drought stress (Table 5). Averaged across experiments, seasonal 
$\mathrm{ET}_{\mathrm{a}}$ of the drought-tolerant hybrid with the optimal $\mathrm{N}$ rate declined by 60 and $97 \mathrm{~mm}$ when drought stress began at R2 and V14, respectively, compared to the well-watered control. When drought stress commenced at V14 with the optimal $\mathrm{N}$ rate, seasonal $\mathrm{ET}_{\mathrm{a}}$ did not differ between hybrids and averaged $366 \mathrm{~mm}$ (Table 4). Maize grain yield is presented in Tables 4 and 5 to assist in the interpretation of $\mathrm{ET}_{\mathrm{a}}$, CWP, and IWP. A detailed description of grain yield in this study was reported by Ao et al. [49].

Table 4. Maize actual crop evapotranspiration $\left(\mathrm{ET}_{\mathrm{a}}\right)$, grain yield, crop water productivity $(\mathrm{CWP})$, irrigation water productivity (IWP), and mid-season actual basal crop coefficient $\left(\mathrm{K}_{\mathrm{ab} \text { mid }}\right)$ for treatments with the optimal nitrogen rate, as influenced by the main effects of drought stress treatment and hybrid.

\begin{tabular}{|c|c|c|c|c|c|c|}
\hline Components of Dataset & Treatment $^{1}$ & $\mathrm{ET}_{\mathbf{a}}$ & Grain Yield & CWP & IWP & $\mathrm{K}_{\mathrm{ab} \text { mid }}$ \\
\hline & & $\mathrm{mm}$ & $\mathrm{kg} \mathrm{m}^{-2}$ & $\mathrm{~kg} \mathrm{~m}^{-3}$ & $\mathrm{~kg} \mathrm{~m}^{-3}$ & \\
\hline \multirow{3}{*}{$\begin{array}{l}\text { Experiment where maize followed soybean, with } \\
\text { four replications of both hybrids subjected to } \\
\text { three drought stress treatments }\end{array}$} & None & $462 \mathrm{a}^{2}$ & $1.374 \mathrm{a}$ & $2.97 \mathrm{a}$ & $3.94 \mathrm{~b}$ & $1.08 \mathrm{a}$ \\
\hline & R2-R6 & $406 \mathrm{~b}$ & $0.932 \mathrm{~b}$ & $2.29 \mathrm{~b}$ & $4.22 \mathrm{~b}$ & $0.89 \mathrm{~b}$ \\
\hline & V14-R6 & $372 \mathrm{c}$ & $0.920 \mathrm{~b}$ & $2.47 \mathrm{~b}$ & $5.01 \mathrm{a}$ & $0.73 \mathrm{c}$ \\
\hline \multirow{3}{*}{$\begin{array}{l}\text { Three experiments, with four replications of the } \\
\text { drought-tolerant hybrid subjected to three } \\
\text { drought stress treatments }\end{array}$} & None & $464 \mathrm{a}$ & $1.459 \mathrm{a}$ & $3.14 \mathrm{a}$ & $4.22 \mathrm{~b}$ & $1.08 \mathrm{a}$ \\
\hline & R2-R6 & $404 \mathrm{~b}$ & $0.981 \mathrm{~b}$ & $2.43 c$ & $4.40 \mathrm{~b}$ & $0.87 \mathrm{~b}$ \\
\hline & V14-R6 & $367 c$ & $0.954 \mathrm{~b}$ & $2.60 \mathrm{~b}$ & $5.32 \mathrm{a}$ & $0.72 \mathrm{c}$ \\
\hline \multirow{2}{*}{$\begin{array}{l}\text { Three experiments, with four replications of both } \\
\text { hybrids subjected to drought stress from V14 to R6 }\end{array}$} & ST & 365 & $0.885 \mathrm{~b}$ & $2.43 \mathrm{~b}$ & $4.94 \mathrm{~b}$ & \\
\hline & DT & 367 & $0.954 \mathrm{a}$ & $2.60 \mathrm{a}$ & $5.32 \mathrm{a}$ & \\
\hline
\end{tabular}

${ }^{1}$ DT: Drought-tolerant hybrid; None: No drought stress; R2-R6: Drought stress from the blister maize phenological stage to maize physiological maturity (R6); ST: Standard hybrid; V14-R6: Drought stress from the 14 leaf collar maize phenological stage to R6. ${ }^{2}$ Within a column for a given dataset, means followed by the same letter are not significantly different $(P \leq 0.05)$.

Table 5. Significance of $F$ tests $(P>F)$ for fixed sources of variation involving drought stress treatment (D) and hybrid $(\mathrm{H})$ on maize seasonal actual crop evapotranspiration $\left(\mathrm{ET}_{\mathrm{a}}\right)$, grain yield, crop water productivity (CWP), irrigation water productivity (IWP), and mid-season actual basal crop coefficient $\left(\mathrm{K}_{\mathrm{ab} \text { mid }}\right)$ for treatments with the optimal nitrogen rate.

\begin{tabular}{|c|c|c|c|c|c|c|}
\hline \multirow{2}{*}{ Components of Dataset } & \multirow{2}{*}{ Source of Variation } & \multicolumn{5}{|c|}{ Dependent Variable } \\
\hline & & $\mathbf{E T}_{\mathbf{a}}$ & Grain Yield & CWP & IWP & $\mathbf{K}_{\mathrm{ab} \text { mid }}$ \\
\hline Experiment where maize followed soybean, with & $\mathrm{D}$ & $<0.001$ & $<0.001$ & 0.001 & $<0.001$ & $<0.001$ \\
\hline four replications of both hybrids subjected to & $\mathrm{H}$ & 0.386 & 0.509 & 0.440 & 0.163 & 0.897 \\
\hline three drought stress treatments & $\mathrm{D} \times \mathrm{H}$ & 0.802 & 0.152 & 0.121 & 0.079 & 0.986 \\
\hline $\begin{array}{l}\text { Three experiments, with four replications of the } \\
\text { drought-tolerant hybrid subjected to three } \\
\text { drought stress treatments }\end{array}$ & $\mathrm{D}$ & $<0.001$ & $<0.001$ & $<0.001$ & $<0.001$ & $<0.001$ \\
\hline $\begin{array}{l}\text { Three experiments, with four replications of both } \\
\text { hybrids subjected to drought stress from V14 to R6 }\end{array}$ & $\mathrm{H}$ & 0.216 & 0.010 & 0.0171 & 0.010 & 0.087 \\
\hline
\end{tabular}

\subsection{Water Productivity}

Crop WP and IWP were influenced by drought stress (Table 5). Across hybrids in the experiment where maize followed soybean, CWP averaged 25\% greater under well-watered conditions compared to when drought stress was imposed, and CWP did not differ between treatments with drought stress from V14 to R6 and R2 to R6 (Table 4). Across hybrids in the experiment where maize followed soybean, IWP averaged 23\% greater when maize was exposed to drought stress beginning at V14 compared to the well-watered control and the treatment where drought stress began at R2. Across experiments for the drought-tolerant hybrid, CWP was 21 and 29\% greater under well-watered conditions compared to when drought stress began at V14 and R2, respectively, and IWP with drought stress commencing at V14 averaged 23\% greater compared to the well-watered control and the treatment with drought stress beginning at R2. Across experiments for the treatment where drought stress began at V14, CWP and IWP were 7 and $8 \%$ greater for the drought-tolerant hybrid than the standard hybrid, respectively, as a result of yield differences because hybrid did not affect $\mathrm{ET}_{\mathrm{a}}$. 


\subsection{Basal Crop Coefficient}

In the experiment where maize followed soybean and received the optimal $\mathrm{N}$ rate, $\mathrm{K}_{\mathrm{ab}}$ mid was influenced by the drought stress treatment, but not by hybrid or interactions with hybrid (Table 5). Averaged across hybrids in the experiment following soybean, $\mathrm{K}_{\mathrm{ab} \text { mid }}$ declined as the duration of drought stress increased (Table 4).

For the drought-tolerant hybrid receiving the optimal $\mathrm{N}$ rate, $\mathrm{K}_{\mathrm{ab}}$ mid was affected by the drought stress treatment (Table 5). Across previous crops for the drought-tolerant hybrid with the optimal $\mathrm{N}$ rate, $\mathrm{K}_{\mathrm{ab} \text { mid }}$ was greater under well-watered conditions than under drought stress (Table 4). Compared to the well-watered control, $\mathrm{K}_{\mathrm{ab} \text { mid }}$ declined by 0.36 and 0.21 when drought stress began at V14 and $\mathrm{R} 2$, respectively. With drought stress imposed at V14 and the optimal $\mathrm{N}$ rate, $\mathrm{K}_{\mathrm{ab}}$ mid did not differ between hybrids.

When maize followed soybean and received the optimal $N$ rate, growth stage-specific $K_{a b}$ was influenced by the interaction between onset of moderate drought stress and phase of maize phenological development $(P<0.001)$. At each stage of maize development from V12 to R6, $\mathrm{K}_{\mathrm{ab}}$ was greatest in the absence of drought (Table 6). Both $\mathrm{K}_{\mathrm{ab}}$ and $\mathrm{K}_{\mathrm{s}}$ declined below those of the well-watered control at the onset of each drought treatment (Figure 2). The field-based $\mathrm{K}_{\mathrm{s}}$ act was slightly higher than the $\mathrm{K}_{\mathrm{s}}$ estimated according to Allen et al. [23] during the period of sustained moderate drought stress. Imposition of drought stress at V14 decreased $\mathrm{K}_{\mathrm{ab}}$ more than drought stress imposed at R2 for most of the subsequent phenological stages.

Table 6. Actual basal crop coefficient $\left(\mathrm{K}_{\mathrm{ab}}\right)$ by maize phenological stage for treatments with no drought stress (None), drought stress from the blister maize phenological stage (R2) to maize physiological maturity (R6) (R2-R6), and drought stress from the 14 leaf collar maize phenological stage (V14) to R6 (V14-R6), across hybrids in the experiment where maize followed soybean and received the optimal nitrogen rate.

\begin{tabular}{cccc}
\hline Maize Phenological Stage $^{\mathbf{1}}$ & None & R2-R6 & V14-R6 \\
\hline V10 & $0.93 \mathrm{dA}^{2}$ & $0.93 \mathrm{cA}$ & $0.93 \mathrm{bA}$ \\
V12 & $1.13 \mathrm{abA}$ & $1.13 \mathrm{aA}$ & $1.02 \mathrm{aB}$ \\
V16 & $1.13 \mathrm{abA}$ & $1.13 \mathrm{aA}$ & $1.06 \mathrm{aB}$ \\
VT & $1.12 \mathrm{abA}$ & $1.07 \mathrm{bB}$ & $0.81 \mathrm{cC}$ \\
R1 & $1.10 \mathrm{bA}$ & $1.13 \mathrm{aA}$ & $0.74 \mathrm{~dB}$ \\
R2 & $1.13 \mathrm{abA}$ & $0.75 \mathrm{~dB}$ & $0.61 \mathrm{efC}$ \\
R3 & $1.12 \mathrm{abA}$ & $0.72 \mathrm{~dB}$ & $0.44 \mathrm{hC}$ \\
R4 & $1.11 \mathrm{bA}$ & $0.63 \mathrm{eB}$ & $0.57 \mathrm{gC}$ \\
Early R5 & $0.84 \mathrm{eA}$ & $0.60 \mathrm{fB}$ & $0.60 \mathrm{efB}$ \\
Mid-R5 & $1.15 \mathrm{aA}$ & $0.65 \mathrm{eB}$ & $0.59 \mathrm{fgC}$ \\
Late R5/R6 $^{3}$ & $0.99 \mathrm{cA}$ & $0.57 \mathrm{gC}$ & $0.63 \mathrm{eB}$ \\
R6 $^{4}$ & $0.64{ }^{5}$ & & \\
\hline
\end{tabular}

${ }_{1}^{1}$ V10: 10 leaf collar; V12: 12 leaf collar; V16: 16 leaf collar; VT: Tasseling; R1: Silking; R3: Milk; R4: Dough; R5: Dent. ${ }^{2}$ Within a column, means followed by the same lowercase letter are not significantly different $(P \leq 0.05)$. Within a row, treatment means followed by the same uppercase letter are not significantly different. ${ }^{3}$ Late R5/R6 represents R5 for the treatment with no drought stress and R6 for the treatments with drought stress. ${ }^{4}$ R6 maize phenological stage for the treatment with no drought stress. ${ }^{5}$ Not included in the statistical analysis. 


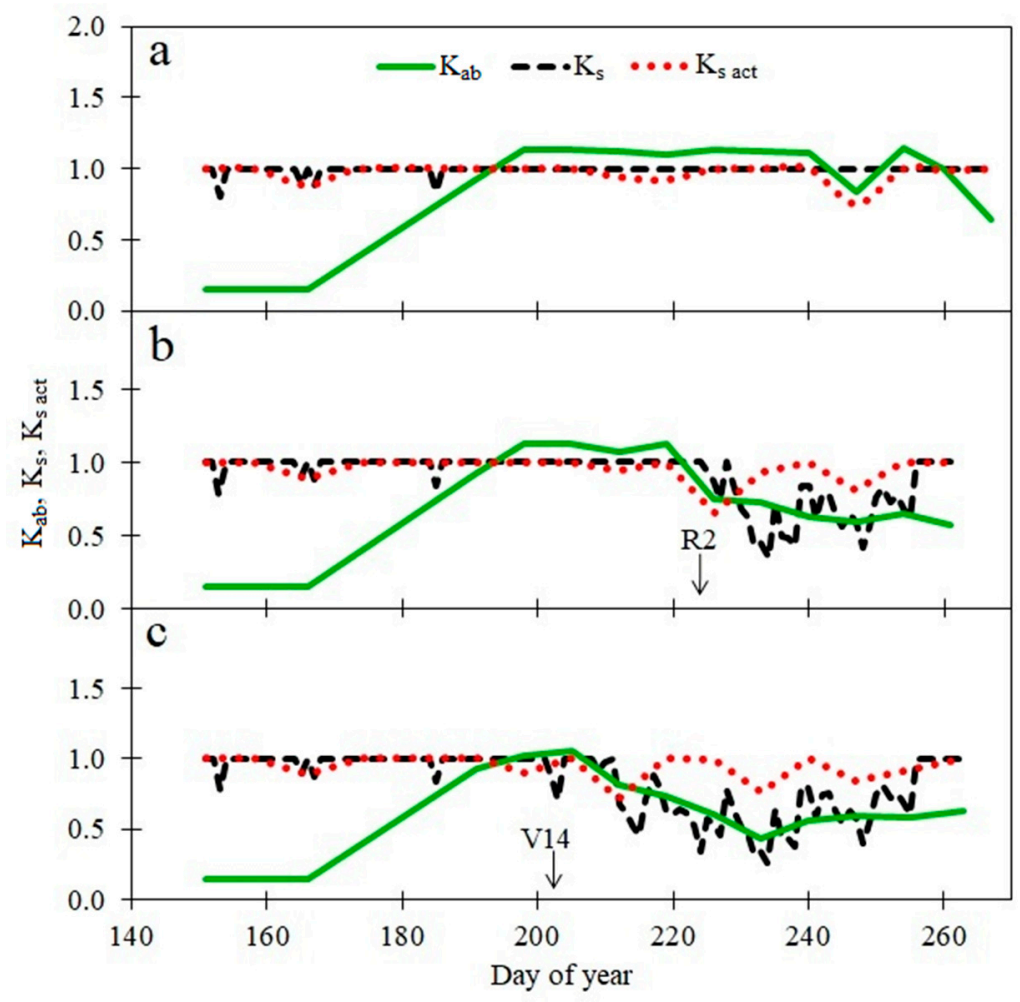

Figure 2. Actual basal crop coefficient $\left(\mathrm{K}_{\mathrm{ab}}\right)$, estimated water stress coefficient $\left(\mathrm{K}_{\mathrm{s}}\right)$ according to Allen et al. [22], and the field-based calculated water stress coefficient $\left(\mathrm{K}_{\mathrm{s}}\right.$ act $)$ of maize by day of year when there was no drought stress (a), drought stress from the blister maize phenological stage (R2) to maize physiological maturity (R6) (b), and drought stress from the 14 leaf collar maize phenological stage (V14) to R6 (c), across hybrids for the experiment where maize followed soybean and received the optimal nitrogen rate.

\section{Discussion}

\subsection{Maize Evapotranspiration}

Results from our research support findings by many others that $\mathrm{ET}_{\mathrm{a}}$ is dependent on maize physiological requirements, maize phenological stage at the onset of drought, and environmental conditions. Our results for the well-watered treatment are consistent with those from Dietzel et al. [8], who reported a minimum threshold of 400 to $450 \mathrm{~mm}$ of seasonal $\mathrm{ET}_{\mathrm{a}}$ for optimum maize growth in the central U.S. Corn Belt, although this varies with seasonal $\mathrm{ET}_{0}$, which is influenced by climatic variables including season length, air temperature, relative humidity, and solar radiation [69]. The range of $\mathrm{ET}_{\mathrm{a}}$ in our experiments is also consistent with the range of 356 to $566 \mathrm{~mm}$ reported for a deficit irrigation study of maize in a temperate climate in Serbia [70]. However, in a longer growing season in the western U.S. Corn Belt with nearly twice as much rainfall, lower relative humidity, and higher solar radiation, Djaman and Irmak [14] reported substantially higher $\mathrm{ET}_{\mathrm{a}}$ (587 to $627 \mathrm{~mm}$ ). Both $\mathrm{ET}_{\mathrm{a}}$ and maize grain yield were reduced by moderate drought, consistent with other reports [14,19]. However, our experiments showed that the grain yield was similar for the two treatments with imposed drought stress, despite lower $\mathrm{ET}_{\mathrm{a}}$ when drought stress began at V14 compared to R2. Thus, our results may indicate that maize achieves more effective physiological acclimation with earlier exposure to drought stress. This was especially apparent for the drought-tolerant hybrid, which produced a similar grain yield with $367 \mathrm{~mm}$ of $\mathrm{ET}_{\mathrm{a}}$ over the longer period of drought stress compared to $404 \mathrm{~mm}^{\text {of }} \mathrm{ET}_{\mathrm{a}}$ with later onset of stress. This implies that additional mid-season water application may not contribute to increased WP. This result is unexpected since the late vegetative to early reproductive period is often reported as the phase when maize is most sensitive to drought stress [34,35]. 


\subsection{Maize Water Productivity}

As found in the experiment where maize followed soybean, greater $\mathrm{ET}_{\mathrm{a}}$ in the absence of drought stress contributed to greater grain yield and greater CWP, supporting previous research showing that CWP is greater when maize is grown under well-watered compared to water deficit conditions [71-73]. However, CWP can be maximized under moderate drought stress $[14,70,74]$ when the relative reduction in grain yield is less than the reduction in $\mathrm{ET}_{\mathrm{a}}$ under deficit irrigation $[15,29,66]$. In our experiments, the drought-tolerant maize hybrid had greater yield and thus CWP and IWP than the standard hybrid under drought stress, but only when drought was initiated at V14. When drought was delayed until R2, prolonged vegetative growth increased $\mathrm{ET}_{\mathrm{a}}$ and subsequent drought stress impaired grain production to a greater extent [49].

This difference between maize hybrids may reflect better physiological acclimation of the drought-tolerant hybrid to reduced $\mathrm{ET}_{\mathrm{a}}$ under water deficit conditions [17]. For the particular drought-tolerant hybrid in the present study, this occurred when extended moderate drought stress began at a late vegetative stage, but not with the later onset of drought. Adaptation of this hybrid to drought stress may have been due to greater stomatal conductance, higher radiation use efficiency, and reduced transpiration rate $[70,75]$, the benefits of which would be enhanced during late vegetative growth [34]. Recognizing that the mechanisms of drought tolerance may differ among improved maize hybrids, we infer that hybrids with similar mechanisms as the one we evaluated may allow farmers to limit water application earlier in maize development than recommended by Payero et al. [19].

\subsection{Basal Crop Coefficient}

In the present study, $\mathrm{K}_{\mathrm{ab} \text { mid }}$ of maize was reduced with the earlier onset (increased duration) of drought stress. Compared to the treatment with drought stress beginning at R2, drought stress beginning at V14 resulted in smaller plants with less leaf area for transpiration [76] and more instances of lower $\mathrm{ET}_{\mathrm{a}}$, which likely contributed to lower $\mathrm{K}_{\mathrm{ab} \text { mid }}$. The treatment with later onset of drought stress had lower $\mathrm{K}_{\mathrm{ab} \text { mid }}$ compared to the well-watered control, possibly because the exposed leaf area for transpiration was reduced by drought stress-induced leaf rolling that we observed in the field [34]. In the absence of drought stress, $\mathrm{K}_{\mathrm{ab} \text { mid }}$ in this study (1.08) was similar to the values reported by previous researchers [23,25,77], slightly higher than the range of 0.96 to 1.02 found by Facchi et al. [78], and 0.18 lower than the grass-based crop coefficient of maize reported by Djaman and Irmak [59]. The lower $\mathrm{K}_{\mathrm{ab} \text { mid }}$ in the two drought stress treatments was associated with less total available water in the 0- to 1.0-m soil layer, which limits evapotranspiration and reduces $\mathrm{ET}_{\mathrm{a}}$ [23].

Growth stage-specific values of $K_{a b}$ throughout the growing season in this study exhibited greater fluctuation when maize was exposed to drought stress. The smaller $K_{a b}$ at V12 for the treatment with drought stress imposed at V14 compared to the other treatments was due to reduced irrigation beginning at the 11 leaf collar maize stage in order to create moderate drought stress by V14. Similarly, the $6 \%$ reduction in $\mathrm{K}_{\mathrm{ab}}$ at tasseling compared to the 16 leaf collar maize phenological stage in the treatment with drought stress from R2 to R6 reflects judicious management of irrigation in preparation for exposing maize to moderate drought stress at $\mathrm{R} 2$. The drop in $\mathrm{K}_{\mathrm{s}}$ act for the well-watered treatment during the late reproductive period was likely caused by soil water storage during the milk stage of maize phenological development that was slightly less than the threshold below which evapotranspiration is reduced to less than potential values, and may have caused some stress in the well-watered treatment. For the treatments with imposed drought stress from V14 to R6 and R2 to R6, $\mathrm{K}_{\mathrm{s}}$ act was only moderately depressed compared to the estimated $\mathrm{K}_{\mathrm{s}}$. This may have been due to the crop being able to physiologically adjust to reduce evapotranspiration [23].

The decline in $\mathrm{K}_{\mathrm{ab}}$ after imposition of drought stress coincided with the gradual decline in calculated $\mathrm{K}_{\mathrm{s}}$ in both drought stress treatments. However, $\mathrm{K}_{\mathrm{ab}}$ did not continue to decline with numerous, periodic declines in $K_{s}$. These results suggest that change in $K_{a b}$ during the drought stress period occurred in two phases that can be categorized as a transitional or intermediate phase and an acclimated phase. During the transitional phase, $\mathrm{K}_{\mathrm{ab}}$ declined as the crop acclimated to increasing crop 
water stress $\left(\mathrm{K}_{\mathrm{s}}\right)$. Once acclimated, little change in $\mathrm{K}_{\mathrm{ab}}$ occurred after sustained moderate drought stress conditions were established, even though $\mathrm{K}_{\mathrm{s}}$ varied widely around a mean. This finding from the field supports the conclusions by Harb et al. [79], based on research conducted with Arabidopsis under highly controlled conditions. The initial decline in $\mathrm{K}_{\mathrm{ab}}$ could have been brought about by the abrupt reduction in soil moisture content that reduced plant water potential, which in turn triggered a physiological mechanism for stomatal control of transpiration and gradual acclimation of $K_{a b}$ to the newly adjusted soil moisture condition [80].

An important determinant of $\mathrm{ET}_{\mathrm{a}}$ for making irrigation decisions is $\mathrm{K}_{\mathrm{ab}}$, which can vary depending on crop phenological stage and growing environment. Our results contribute to better estimation of $\mathrm{K}_{\mathrm{ab}}$ for more precise irrigation management, especially when maize experiences prolonged, moderate drought stress.

\section{Conclusions}

This research was conducted under conditions that may well become more common as climate change alters rainfall amounts and timing in many temperate, humid, and sub-humid areas. Using a soil with relatively limited water holding capacity and a precision drip irrigation system allowed us to control the severity of drought stress. We exposed a standard maize hybrid and a drought-tolerant maize hybrid to extended periods of moderate drought stress, evidenced by midday leaf rolling that was relieved overnight. Imposition of drought stress during late vegetative development improved CWP compared to stress initiated during early reproductive development, even though these treatments produced a similar grain yield. The drought-tolerant hybrid showed greater improvement in IWP with a longer duration of drought stress than the standard hybrid.

We observed two phases of the crop coefficient, $\mathrm{K}_{\mathrm{ab}}$, in response to drought: an initial transitional phase represented by declining $\mathrm{K}_{\mathrm{ab}}$, followed by an acclimated phase with stable $\mathrm{K}_{\mathrm{ab}}$. If drought is prolonged, two subdivisions of $\mathrm{K}_{\mathrm{ab}}$ may be required to estimate irrigation requirements accurately. In addition, it appears that maize can achieve a more effective physiological acclimation with earlier exposure to drought stress, since grain yield did not differ between the shorter and longer drought periods we imposed.

Author Contributions: Conceptualization, J.A.C. and M.P.R.; methodology, J.A.C., M.P.R., G.W.F., T.V., and S.A.; validation, J.A.C., M.P.R., and G.W.F.; formal analysis, S.A., J.A.C., M.P.R., and G.W.F.; investigation, S.A., J.A.C., T.V., M.P.R., and G.W.F.; resources, J.A.C., M.P.R., and G.W.F.; data curation, S.A. and J.A.C.; writing-original draft preparation, S.A. and J.A.C.; writing-review and editing, J.A.C., M.P.R., G.W.F., T.V., and S.A.; visualization, J.A.C., M.P.R., G.W.F., S.A., and T.V.; supervision, J.A.C., M.P.R., and G.W.F.; project administration, J.A.C.; funding acquisition, J.A.C. All authors have read and agreed to the published version of the manuscript.

Funding: This research was funded by the Minnesota Corn Research and Promotion Council, grant 4099-13SP.

Acknowledgments: The authors appreciate technical assistance from Eric Ristau, Ronald Faber, Todd Schumacher, Peter Boulay, and several others.

Conflicts of Interest: The authors declare no conflict of interest.

\section{References}

1. Dai, A. Increasing drought under global warming in observations and models. Nat. Clim. Chang. 2013, 3, 52-58. [CrossRef]

2. DeLucia, E.H.; Chen, S.; Guan, K.; Peng, B.; Li, Y.; Gomez-Casanovas, N.; Kantola, I.B.; Bernacchi, C.J.; Huang, Y.; Long, S.P.; et al. Are we approaching a water ceiling to maize yields in the United States? Ecosphere 2019, 10, e02773. [CrossRef]

3. Daryanto, S.; Wang, L.; Jacinthe, P.A. Global synthesis of drought effects on food legume production. PLoS ONE 2015, 10, e0127401. [CrossRef] [PubMed]

4. Daryanto, S.; Wang, L.; Jacinthe, P.A. Global synthesis of drought effects on maize and wheat production. PLoS ONE 2016, 11, e0156362. [CrossRef] [PubMed] 
5. Nair, S.; Johnson, J.; Wang, C. Efficiency of irrigation water use: A review from the perspectives of multiple disciplines. Agron. J. 2013, 105, 351-363. [CrossRef]

6. Irmak, S.; Djaman, K.; Sharma, V. Winter wheat (Triticum aestivum L.) evapotranspiration and single (normal) and basal crop coefficients. Trans. Am. Soc. Agric. Eng. 2015, 58, 1047-1066.

7. Kumar, V.; Udeigwe, T.K.; Clawson, E.L.; Rohli, R.V.; Miller, D.K. Crop water use and stage-specific crop coefficients for irrigated cotton in the mid-south, United States. Agric. Water Manag. 2015, 156, 63-69. [CrossRef]

8. Dietzel, R.; Liebman, M.; Ewing, R.; Helmers, M.; Horton, R.; Jarchow, M.; Archontoulis, S. How efficiently do corn-and soybean-based cropping systems use water? A systems modeling analysis. Glob. Change Biol. 2016, 22, 666-681. [CrossRef]

9. Molden, D.; Murray-Rust, H.; Sakthivadivel, R.; Makin, I. A Water-Productivity Framework for Understanding and Action. In Water Productivity in Agriculture: Limits and Opportunities for Improvement; Kijne, J.W., Barker, R., Molden, D., Eds.; International Water Management Institute: Colombo, Sri Lanka, 2003; pp. 1-18.

10. Geerts, S.; Raes, D. Deficit irrigation as an on-farm strategy to maximize crop water productivity in dry areas. Agric. Water Manag. 2009, 96, 1275-1284. [CrossRef]

11. Li, X.; Zhang, X.; Niu, J.; Tong, L.; Kang, S.; Du, T.; Li, S.; Ding, R. Irrigation water productivity is more influenced by agronomic practice factors than by climatic factors in Hexi Corridor, Northwest China. Sci. Rep. 2016, 6, 37971. [CrossRef]

12. Sadler, E.J.; Bauer, P.J.; Busscher, W.J.; Millen, J.A. Site-specific analysis of a droughted corn crop: II. Water use and stress. Agron. J. 2000, 92, 403-410. [CrossRef]

13. Hao, B.; Xue, Q.; Marek, T.H.; Jessup, K.E.; Becker, J.; Hou, X.; Xu, W.; Bynum, E.D.; Bean, B.W.; Colaizzi, P.D.; et al. Water use and grain yield in drought-tolerant corn in the Texas High Plains. Agron. J. 2015, 107, 1922-1930. [CrossRef]

14. Djaman, K.; Irmak, S. Soil water extraction patterns and crop, irrigation, and evapotranspiration water use efficiency of maize under full and limited irrigation and rainfed settings. Trans. Am. Soc. Agric. Eng. 2012, 55, 1223-1238. [CrossRef]

15. Panda, R.K.; Behera, S.K.; Kashyap, P.S. Effective management of irrigation water for maize under stressed conditions. Agric. Water Manag. 2004, 66, 181-203. [CrossRef]

16. Hernández, M.; Echarte, L.; Della Maggiora, A.; Cambareri, M.; Barbieri, P.; Cerrudo, D. Maize water use efficiency and evapotranspiration response to $\mathrm{N}$ supply under contrasting soil water availability. Field Crops Res. 2015, 178, 8-15. [CrossRef]

17. Tolk, J.A.; Evett, S.R.; Xu, W.; Schwartz, R.C. Constraints on water use efficiency of drought tolerant maize grown in a semi-arid environment. Field Crops Res. 2016, 186, 66-77. [CrossRef]

18. Blum, A. Effective use of water (EUW) and not water-use efficiency (WUE) is the target of crop yield improvement under drought stress. Field Crops Res. 2009, 112, 119-123. [CrossRef]

19. Payero, J.O.; Tarkalson, D.D.; Irmak, S.; Davison, D.; Petersen, J.L. Effect of timing of a deficit-irrigation allocation on corn evapotranspiration, yield, water use efficiency and dry mass. Agric. Water Manag. 2009, 96, 1387-1397. [CrossRef]

20. Bausch, W.; Trout, T.; Buchleiter, G. Evapotranspiration adjustments for deficit irrigated corn using canopy temperature: A concept. Irrig. Drain. 2011, 60, 682-693. [CrossRef]

21. Rudnick, D.R.; Irmak, S. Impact of water and nitrogen management strategies on maize yield and water productivity indices under linear-move sprinkler irrigation. Trans. Asabe 2013, 56, 1769-1783.

22. Ogola, J.B.O.; Wheeler, T.R.; Harris, P.M. Effects of nitrogen and irrigation on water use of maize crops. Field Crops Res. 2002, 78, 105-117. [CrossRef]

23. Allen, R.G.; Pereira, L.S.; Raes, D.; Smith, M. Crop. Evapotranspiration Guidelines for Computing Crop Water Requirements. Irrig. Drainage Paper 56; Food Agriculture Organization: Rome, Italy, 1998.

24. Allen, R.G. Using the FAO-56 dual crop coefficient method over an irrigated region as part of an evapotranspiration intercomparison study. J. Hydrol. 2000, 229, 27-41. [CrossRef]

25. Piccinni, G.; Ko, J.; Marek, T.; Howell, T. Determination of growth-stage-specific crop coefficients $\left(\mathrm{K}_{\mathrm{c}}\right)$ of maize and sorghum. Agric. Water Manag. 2009, 96, 1698-1704. [CrossRef]

26. El-Hendawy, S.E.; El-Lattief, E.A.A.; Ahmed, M.S.; Schmidhalter, U. Irrigation rate and plant density effects on yield and water use efficiency of drip-irrigated corn. Agric. Water Manag. 2008, 95, 836-844. [CrossRef] 
27. Lindsey, A.J. Agronomic and Physiological Responses Modern Drought-Tolerant Maize (Zea mays L.) hybrids to Agronomic Production Practices. Ph.D. Thesis, Ohio State University, Columbus, OH, USA, 2015.

28. Irmak, S.; Mohammed, A.T.; Kranz, W.L. Grain yield, crop and basal evapotranspiration, production functions, and water productivity response of drought-tolerant and non-drought-tolerant maize hybrids under different irrigation levels, population densities, and environments: Part II. In south-central and northeast Nebraska's transition zone and sub-humid environments. Appl. Eng. Agric. 2019, 35, 83-102.

29. Kang, S.; Gu, B.; Du, T.; Zhang, J. Crop coefficient and ratio of transpiration to evapotranspiration of winter wheat and maize in a semi-humid region. Agric. Water Manag. 2003, 59, 239-254. [CrossRef]

30. Aydinsakir, K.; Erdal, S.; Buyuktas, D.; Bastug, R.; Toker, R. The influence of regular deficit irrigation applications on water use, yield, and quality components of two corn (Zea mays L.) genotypes. Agric. Water Manag. 2013, 128, 65-71. [CrossRef]

31. Cairns, J.E.; Hellin, J.; Sonder, K.; Araus, J.L.; MacRobert, J.F.; Thierfelder, C.; Prasanna, B.M. Adapting maize production to climate change in sub-Saharan Africa. Food Secur. 2013, 5, 345-360. [CrossRef]

32. Lobell, D.B.; Roberts, M.J.; Schlenker, W.; Braun, N.; Little, B.B.; Rejesus, R.M.; Hammer, G.L. Greater sensitivity to drought accompanies maize yield increase in the US Midwest. Science 2014, 344, 516-519. [CrossRef]

33. National Drought Mitigation Center. U.S. Drought Monitor Map Archive. Univ. of Nebraska, Lincoln. Available online: https://droughtmonitor.unl.edu/maps/maparchive.aspx (accessed on 10 September 2020).

34. Çakir, R. Effect of water stress at different development stages on vegetative and reproductive growth of corn. Field Crops Res. 2004, 89, 1-16. [CrossRef]

35. Kranz, W.L.; Irmak, S.; Van Donk, S.J.; Yonts, C.D.; Martin, D.L. Irrigation Management for Corn. Nebguide G1850. Univ. of Nebraska, Lincoln. 2008. Available online: http://extensionpublications. unl.edu/assets/html/g1850/build/g1850.htm (accessed on 10 September 2020).

36. Sharma, V.; Irmak, S.; Djaman, K.; Sharma, V. Large-scale spatial and temporal variability in evapotranspiration, crop water-use efficiency, and evapotranspiration water-use efficiency of irrigated and rainfed maize and soybean. J. Irrig. Drain. Eng. 2015, 142, 04015063. [CrossRef]

37. Lu, Y.; Zhang, X.; Chen, S.; Shao, L.; Sun, H. Changes in water use efficiency and water footprint in grain production over the past 35 years: A case study in the North China Plain. J. Clean. Prod. 2016, 116, 71-79. [CrossRef]

38. Lopes, M.S.; Araus, J.L.; Van Heerden, P.D.; Foyer, C.H. Enhancing drought tolerance in C $_{4}$ crops. J. Exp. Bot. 2011, 62, 3135-3153. [CrossRef] [PubMed]

39. Edmeades, G.O. Progress in Achieving and Delivering Drought Tolerance in Maize-An Update; ISAAA: Ithaca, NY, USA, 2013.

40. Edmeades, G.O.; Chapman, S.C.; Lafitte, H.R. Selection improves drought tolerance in tropical maize populations: I. Gains in biomass, grain yield, and harvest index. Crop. Sci. 1999, 39, 1306-1315. [CrossRef]

41. Tollenaar, M.; Lee, E.A. Yield potential, yield stability and stress tolerance in maize. Field Crops Res. 2002, 75, 161-169. [CrossRef]

42. Campos, H.; Cooper, M.; Habben, J.E.; Edmeades, G.O.; Schussler, J.R. Improving drought tolerance in maize: A view from industry. Field Crops Res. 2004, 90, 19-34. [CrossRef]

43. Campos, H.; Cooper, M.; Edmeades, G.O.; Loffler, C.; Schussler, J.R.; Ibanez, M. Changes in drought tolerance in maize associated with fifty years of breeding for yield in the US Corn Belt. Maydica 2006, 51, 369-381.

44. Roth, J.A.; Ciampitti, I.A.; Vyn, T.J. Physiological evaluations of recent drought-tolerant maize hybrids at varying stress levels. Agron. J. 2013, 105, 1129-1141. [CrossRef]

45. USDA-Natural Resources Conservation Service. Web Soil Survey. Available online: http://websoilsurvey. nrcs.usda.gov/ (accessed on 10 September 2020).

46. Rehm, G.W.; Malzer, G.L.; Wright, J.A. Managing Nitrogen for Corn Production on Iirrigated Sandy Soils; University of Minnesota Extension: St. Paul, MN, USA, 1989; Available online: http://www.wadenaswcd. org/AG-FO-2392-1.pdf (accessed on 10 September 2020).

47. Rehm, G.W.; Lamb, J.; Rosen, C.; Randall, G. Best Management Pracrtices for Nitrogen on Coarse Textured Soils; University of Minnesota Extension: St. Paul, MN, USA, 2008. Available online: https://conservancy.umn. edu/handle/11299/198230 (accessed on 10 September 2020). 
48. Kaiser, D.E.; Lamb, J.A.; Eliason, R. Fertilizer Guidelines for Agronomic Crops in Minnesota; BU-06240-S; University of Minnesota Extension: St. Paul, MN, USA, 2011. Available online: https: //conservancy.umn.edu/bitstream/handle/11299/198924/Fertilizer\%20Guidelines\%20for\%20Agronomic\% 20Crops\%20in\%20Minnesota.pdf?sequence=1\&isAllowed=y (accessed on 10 September 2020).

49. Ao, S.; Russelle, M.P.; Varga, T.; Feyereisen, G.W.; Coulter, J.A. Drought tolerance in maize is influenced by timing of drought stress initiation. Crop. Sci 2020, 60, 1591-1606. [CrossRef]

50. Cresswell, H.P.; Hamilton, J.G. Bulk density and pore space relations. In Soil Physical Measurement and Interpretation for Land Evaluation; McKenzie, N.J., Coughlan, K.L., Cresswell, H.P., Eds.; CSIRO Publishing: Collingwood, Australia, 2002; pp. 35-58.

51. Allen, R.G.; Pereira, L.S.; Smith, M.; Raes, D.; Wright, J.L. FAO-56 dual crop coefficient method for estimating evaporation from soil and application extensions. Irrig. Drain. Eng. 2005, 131, 2-13. [CrossRef]

52. Schmidt, J.P.; Sripada, R.P.; Beegle, D.B.; Rotz, C.A.; Hong, N. Within-field variability in optimum nitrogen rate for corn linked to soil moisture availability. Soil Sci. Soc. Am. J. 2011, 75, 306-316. [CrossRef]

53. Varga, T.; Feyereisen, G.W.; Russelle, M.P.; Ao, S.; Coulter, J.A. Versatile, precise drip irrigation system for agronomic small-plot research. In Proceedings of the ASABE 2018 Annual International Meeting, Detroit, MI, USA, 19 July-1 August 2018. Available online: https://doi.org/10.13031/aim.201801700 (accessed on 10 September 2020).

54. Wright, J. Irrigation Scheduling Checkbook Method; University of Minnesota Extension: St. Paul, MN, USA, 2002; Available online: https://extension.umn.edu/irrigation/irrigation-scheduling-checkbook-method (accessed on 10 September 2020).

55. Schaefer, G.L.; Cosh, M.H.; Jackson, T.J. The USDA Natural Resources Conservation Service Soil Climate Analysis Network (SCAN). J. Atmos. Ocean. Technol. 2007, 24, 2073-2077. [CrossRef]

56. USDA-Natural Resources Conservation Service National Water and Climate Center. Soil Climate Analysis Network (SCAN). Available online: https://www.wcc.nrcs.usda.gov/scan/scan_brochure.pdf (accessed on 10 September 2020).

57. USDA-Natural Resources Conservation Service National Water and Climate Center. Scan Site: Crescent Lake \#1. Available online: https://wcc.sc.egov.usda.gov/nwcc/site?sitenum=2002 (accessed on 10 September 2020).

58. USDA-Natural Resources Conservation Service. Chapter 10: Hydrology. National English Handbook; USDA: Washington, DC, USA, 2004.

59. Djaman, K.; Irmak, S. Actual crop evapotranspiration and alfalfa- and grass-reference crop coefficients of maize under full and limited irrigation and rainfed conditions. J. Irrig. Drain. Eng. 2013, 139, 433-446. [CrossRef]

60. Suleiman, A.A.; Soler, C.M.T.; Hoogenboom, G. Evaluation of FAO-56 crop coefficient procedures for deficit irrigation management of cotton in a humid climate. Agric. Water Manag. 2007, 91, 33-42. [CrossRef]

61. Allen, R.G.; Pereira, L.S.; Howell, T.A.; Jensen, M.E. Evapotranspiration information reporting: I. Factors governing measurement accuracy. Agric. Water Manag. 2011, 98, 899-920. [CrossRef]

62. Allen, R.G.; Pereira, L.S.; Howell, T.A.; Jensen, M.E. Evapotranspiration information reporting: II. Recommended documentation. Agric. Water Manag. 2011, 98, 921-929. [CrossRef]

63. SAS Institute. The SAS system for Windows; Version 9.3; SAS Institute: Cary, NC, USA, 2011.

64. Kutner, M.H.; Nachtsheim, C.J.; Neter, J. Applied Linear Regression Models, 4th ed.; McGraw-Hill: New York, NY, USA, 2004; pp. 107-152.

65. Crafts-Brandner, S.J.; Salvucci, M.E. Sensitivity of photosynthesis in a $\mathrm{C}_{4}$ plant, maize, to heat stress. Plant. Physiol. 2002, 129, 1773-1780. [CrossRef]

66. Trout, T.J.; DeJonge, K.C. Water productivity of maize in the US high plains. Irrig. Sci. 2017, 35, 251-266. [CrossRef]

67. Ao, S. Morpho-Physiological Traits Associated with Drought Tolerance of Maize Hybrids Subjected to Different Water and Nitrogen Supply. Ph.D. Thesis, University of Minnesota, Twin Cities, MN, USA, 2016. Available online: http://hdl.handle.net/11299/185203 (accessed on 10 September 2020).

68. Trout, T.J.; DeJonge, K.C. Crop water use and crop coefficients of maize in the Great Plains. J. Irrig. Drain. Eng. 2018, 144, 04018009. [CrossRef]

69. Wang, K.; Xu, Q.; Li, T. Does recent climate warming drive spatiotemporal shifts in functioning of high-elevation hydrological systems? Sci. Total Environ. 2020, 719, 137507. [CrossRef] 
70. Kresović, B.; Tapanarova, A.; Tomić, Z.; Životić, L.; Vujović, D.; Sredojević, Z.; Gajić, B. Grain yield and water use efficiency of maize as influenced by different irrigation regimes through sprinkler irrigation under temperate climate. Agric. Water Manag. 2016, 169, 34-43. [CrossRef]

71. Igbadun, H.E.; Salim, B.A.; Tarimo, A.K.P.R.; Mahoo, H.F. Effects of deficit irrigation scheduling on yields and soil water balance of irrigated maize. Irrig. Sci. 2008, 27, 11-23. [CrossRef]

72. Howell, T.A.; Schneider, A.D.; Evett, S.R. Subsurface and surface microirrigation of corn —Southern High Plains. Trans. Am. Soc. Agric. Eng. 1997, 40, 635-641. [CrossRef]

73. Couto, A.; Padín, A.R.; Reinoso, B. Comparative yield and water use efficiency of two maize hybrids differing in maturity under solid set sprinkler and two different lateral spacing drip irrigation systems in León, Spain. Agric. Water Manag. 2013, 124, 77-84. [CrossRef]

74. Otegui, M.E.; Andrade, F.H.; Suero, E.E. Growth, water use, and kernel abortion of maize subjected to drought at silking. Field Crop. Res. 1995, 40, 87-94. [CrossRef]

75. Mansouri-Far, C.; Sanavy, S.A.M.M.; Saberali, S.F. Maize yield response to deficit irrigation during low-sensitive growth stages and nitrogen rate under semi-arid climatic conditions. Agric. Water Manag. 2010, 97, 12-22. [CrossRef]

76. Facchi, A.; Gharsallah, O.; Corbari, C.; Masseroni, D.; Mancini, M.; Gandolfi, C. Determination of maize crop coefficients in humid climate regime using the eddy covariance technique. Agric. Water Manag. 2013, 130, 131-141. [CrossRef]

77. Lee, E.A.; Tollenaar, M. Physiological basis of successful breeding strategies for maize grain yield. Crop. Sci. 2007, 47, S-202-S-215. [CrossRef]

78. Escobar-Gutiérrez, A.J.; Combe, L. Senescence in field-grown maize: From flowering to harvest. Field Crops Res. 2012, 134, 47-58. [CrossRef]

79. Harb, A.; Krishnan, A.; Ambavaram, M.M.R.; Pereira, A. Molecular and physiological analysis of drought stress in Arabidopsis reveals early responses leading to acclimation in plant growth. Plant. Physiol. 2010, 154, 1254-1271. [CrossRef]

80. Osakabe, Y.; Osakabe, K.; Shinozaki, K.; Tran, L.S. Response of plants to water stress. Front. Plant. Sci. 2014, 5, 86. [CrossRef] [PubMed] 